\title{
Hepatic ischemia-reperfusion and its effects on duodenal anastomosis healing
}

\section{Isquemia-reperfusão hepática e seus efeitos na cicatrização de anastomoses duodenais}

Caroline Manoela de Oliveira, Catharinne Keyth Mendes de Oliveira, Jéssica Jacinto Salviano de Almeida, Vítor Brasil Medeiros, Rafael Pereira do Nascimento, Ítalo Medeiros Azevedo, Aldo Cunha Medeiros

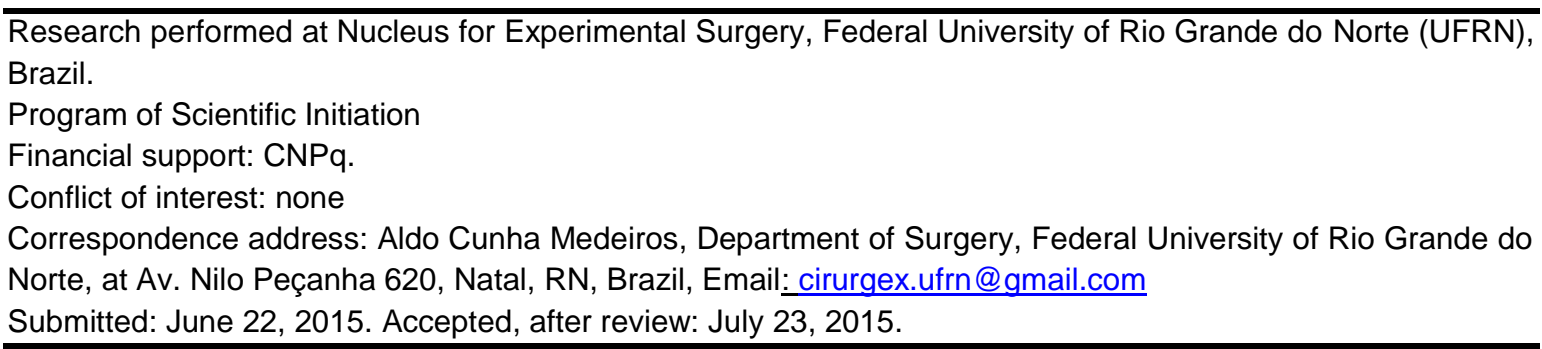

\begin{abstract}
:
Background/objetive: The liver ischemia and reperfusion is important for procedures occurring in liver and intestinal trauma injuries that require intestinal resection and anastomosis. The aim of this study was to evaluate the influence of hepatic ischemia/reperfusion in vivo in the healing of duodenal anastomoses. Methods: Wistar rats were randomly selected and allocated into two groups of six animals each: liver ischemia/reperfusion + duodenal anastomosis group and duodenal anastomoses group. Hepatic ischemia was induced for 30 minutes by occlusion of the vessels that supply the median and lateral lobes of the liver, using a microvascular clip. In all rats the duodenum was sectioned and an end-to-end anastomosis was performed. After liver reperfusion, animals were observed for 6 days; the maximum bursting pressure of anastomoses was determined and duodenum samples were taken for histopathological examination. Results: As a result, the maximum bursting pressure of anastomosis in ischemia/reperfusion + duodenal anastomosis group $(64.5 \pm 5.5 \mathrm{mmHg})$ was significantly lower $(p<0.001)$ than in duodenal anastomosis group rats $(89.7 \pm 3.4 \mathrm{mmHg})$. The inflammatory tissue response in ischemia/reperfusion + duodenal anastomosis group had scores higher than in duodenal anastomosis group rats $(p=0.004)$. Conclusion: In conclusion, the hepatic ischemia-reperfusion negatively affected the healing process of duodenal anastomoses.
\end{abstract}

Key words: Liver. Ischemia/reperfusion. Duodenum. Anastomosis. Healing. 


\section{RESUMO:}

Objetivo: A isquemia e reperfusão hepática é um dos temas mais estudados em cirurgia experimental, sendo importante para os procedimentos que ocorrem em lesões hepáticas e trauma abdominal que requerem ressecção intestinal e anastomose. O objectivo deste estudo é avaliar a influência da isquemia/reperfusão hepática in vivo na cicatrização de anastomoses duodenais. Métodos: Ratos Wistar foram selecionados e distribuídos em dois grupos de seis animais cada: grupo isquemia/reperfusão hepática+anastomose duodenal e grupo anastomose duodenal. A isquemia foi induzida por 30 minutos pela oclusão dos vasos que irrigam os lobos mediano e lateral do fígado, utilizando um clipe microvascular. Em seguida em todos os ratos o duodeno foi seccionado e uma anastomose término-terminal foi realizada. Após reperfusão, os animais foram observados durante 6 dias; a pressão máxima de ruptura das anastomoses foi determinada e amostras das zonas de anastomoses foram obtidas para exame histopatológico. Resultados: A pressão máxima de ruptura da anastomose duodenal no grupo isquemia/reperfusão+anastomose $(64,5 \pm 5.5 \mathrm{mmHg})$ foi significativamente menor $(p<0,001)$ do que nos ratos do grupo de anastomose duodenal $(89,7 \pm 3.4 \mathrm{mmHg})$. A resposta inflamatória tecidual nos animais do grupo isquemia/reperfusão+anastomose duodenal teve escores mais elevados do que nos ratos do grupo anastomose duodenal $(p=0,004)$. Conclusão: Em conclusão, a isquemia/reperfusão hepática afetou negativamente o processo de cicatrização de anastomoses duodenais.

Descritores: Fígado. Isquemia/reperfusão. Duodeno. Anastomose. Cicatrização.

\section{INTRODUCTION}

Anastomosis refers to natural or artificial communication between two blood vessels or between tubular organs, like intestines. The main complications of anastomosis in the intestinal tract are dehiscence, fistulas and stenosis. ${ }^{1}$

By putting the sectioned edges of the intestinal loops together, anastomosis promotes healing. This process is part of tissue regeneration, which, in turn, consists of the steps: inflammation, proliferation and maturation occurring together with the remodeling of tissues and contraction of the wound. ${ }^{2}$ Various situations can affect the healing process of intestinal anastomosis, such as malnutrition and protein deficiency, lack of vitamins, severe anemia, ischemia, diabetes mellitus, the use of chemotherapeutic agents, prostaglandins, uremia, etc. ${ }^{3}$

Ischemia, with its subsequent lack of oxygen and nutrients, is a phenomenon inherent to different surgical procedures. In liver surgery, there are situations in which ischemia periods can be particularly long, such as during resection of hepatocarcinomas, in hepatic trauma surgery, ${ }^{4}$ vascular reconstructions, ${ }^{5}$ and liver transplantation. ${ }^{6}$ 
Within a period of ischemia, various functional changes will occur at the cellular level, promoting cell damage. A reduction in oxidative phosphorylation results in the depletion of adenosine triphosphate (ATP) and in calcium homeostasis disorders. ${ }^{7}$ The deleterious effects of ATP catabolism modification are reinforced by the production of various substances, including reactive oxygen species (ROS), cytokines, adhesion molecules, and vasoactive agents (endothelin and thromboxane-A2). These changes are accompanied by a decrease of cytoprotective substances ${ }^{8}$ including nitric oxide, prostacyclin, and others. ${ }^{9}$ Under these conditions, hepatic cell death occurs due to apoptosis and necrosis. ${ }^{10}$

Once the blood flow and oxygen supply is restored, the reperfusion increases the damage caused by ischemia, ${ }^{11}$ aggravating the damage at the cellular level. ${ }^{12}$ This phenomenon is known as ischemia/reperfusion $(\mathrm{I} / \mathrm{R})$, and directly impacts the viability of the liver and changes in other organs, especially during transplant and hepatic surgery. ${ }^{13}$

This injury is one of the most studied aspects in experimental surgery, being extremely important for procedures occurring in liver and intestinal trauma injuries that require intestinal resection and anastomosis. In such cases, the Pringle maneuver consisting of clamping the hepatic pedicle (containing the common bile duct, hepatic artery and portal vein) is important to limit bleeding coming from hepatic damage, while the surgeon makes sutures and anastomoses in the injured duodenum, small intestine, colon and other organs. ${ }^{14}$

Thus, it is necessary to understand the metabolic processes resulting from $I / R$ and its relationship with intestinal anastomoses in order to prevent anastomotic dehiscence. These in turn are important complications in post-operative recovery of the digestive tract as they increase the morbidity and mortality of patients ${ }^{15}$ and cause major impact on health care costs. ${ }^{16}$

In addition to a social contribution, this study seeks to innovate in academics, since the influence of hepatic ischemia-reperfusion in the healing of duodenal anastomosis is still a subject that is little explored in the literature. Bibliographical searches in the databases of PubMed and SciElo using the keywords ischemia-reperfusion, liver, healing, and duodenum showed only 14 references, none of which were specifically concerned with the present protocol.

The objective of this study was to evaluate in vivo the influence of hepatic ischemia/reperfusion in the healing of duodenal anastomosis in rats by examining the resistance of anastomosis bursting strength and histopathology of duodenal healing on anastomoses zones. 


\section{METHODS}

\section{Animals}

Male Wistar (Rattus norvegicus) rats weighing $275 \pm 32 \mathrm{~g}$ were used for all experiments. This study was submitted to and approved by the University Ethics Committee on Animal Use (Protocol $n^{\circ}$ 037/2014). Care in the use of animals followed current regulations in Brazilian legislation for the scientific use of animals (Law No. 11,794/2008). The study was conducted in the Nucleus of Experimental Surgery (NES), Department of Surgery, UFRN, Brazil. Rats were individually housed in the NES Vivarium under a light:dark cycle of 12:12. Rats were allowed free access to rodent chow (Presence ${ }^{\circledR}$ ) and water ad libitum. Before the beginning of the experiments the rats were 7 days at the laboratory for acclimation.

\section{Experimental Design}

The animals were randomly selected and allocated into 2 groups of 6 each: Ischemia/reperfusion+duodenal anastomosis group; duodenal anastomosis group. Rats were anesthetized with a combination of ketamine $70 \mathrm{mg} / \mathrm{kg}+$ xylazine $10 \mathrm{mg} / \mathrm{kg}$ i.m., and operated under aseptic technique. Post-operative analgesia was done with $10 \mathrm{mg} / \mathrm{kg}$ meperidine administered subcutaneously every 12 hours during the first 3 days.

\section{Surgical Procedures}

They were performed by a surgeon with extensive experience in surgery on small laboratory animals. A median $04 \mathrm{~cm}$ laparotomy and other procedures occurred as described below:

Ischemia/reperfusion+duodenal anastomosis Group $(n=6)$ : Hepatic ischemia was induced for 30 minutes by occlusion of the vessels that supply the median and lateral liver lobes, using a microvascular clip (bulldog). Throughout the ischemia period, the abdomen was temporarily closed by suture. After the removal of the vascular clip, reperfusion ensued. Then the duodenum was sectioned and end-to-end anastomosis was performed using $\mathrm{n}^{\circ}$ 6-0 polypropylene thread. A surgical microscope amplified 10x was used (DFVasconcelos, São Paulo, SP).

Duodenal Anastomosis Group $(n=6)$ : The duodenum was sectioned and end-to-end anastomosis was performed using a $n^{\circ}$ 6-0 polypropylene thread in separate points. Animals were observed for six days in the post-operative observation room of the Nucleus of Experimental Surgery, Department of Surgery, UFRN. 
On postoperative day 6 , all rats were anesthetized with the same dosage of ketamine/xylazine mixture. A second laparotomy was carried out, at which time the anastomosis site was identified. Particular attention was paid to keeping peri-anastomotic adhesions in their natural place. To measure bursting pressure in vivo, a plastic no 6 catheter was inserted into the duodenal lumen at a point $4 \mathrm{~cm}$ proximal to the anastomosis, and a 4-0 cotton ligature sealed the duodenum and catheter. A ligature with 4-0 cotton was performed $5 \mathrm{~cm}$ distal to the duodenal anastomosis. An infusion $\mathrm{O}_{2}$ system hooked up to a digital manometer was connected to the intraluminally placed catheter. The duodenum remained in the abdominal cavity, which was filled with $0.9 \%$ saline. An infusion of oxygen $\left(\mathrm{O}_{2}\right)$ was done under pressure in the duodenal lumen at a rate of 3 Liters/minute. When air bubbles were observed in the liquid mass, we determined maximum bursting pressure of the anastomosis. Then the rats were euthanized with $100 \mathrm{mg} / \mathrm{Kg}$ thiopental i.p.

Samples containing duodenal anastomoses were harvested and fixed in 10\% formalin in separate vials. They were embedded in paraffin blocks and histological sections of $5 \mu \mathrm{m}$ were stained with hematoxylin and eosin. Histopathological analysis was done by the criteria used by Storchet et al. ${ }^{17}$ According to these criteria, deposition of collagen, fibrosis and mean number of fibroblasts received positive scores (Square 1). The presence of inflammatory cells (inflammation) and foreign body reaction were considered poor or immature healing signs and received negative scores.

Square 1 - Quantification of the scores resulting from the response to healing

\begin{tabular}{|l|c|c|}
\hline \multicolumn{1}{|c|}{ PARAMETERS } & SCALE & DEFINITION \\
\hline Collagen & 1 to 4 & weak=1; mild=2; strong=3; intense=4 \\
\hline Fibroses & 1 to 4 & weak=1; mild=2; strong=3; intense=4 \\
\hline Fibroblasts & 1 to 4 & Overall volume of fibroblasts \\
\hline Reaction from foreign body & -1 to -4 & Reaction intensity \\
\hline Inflammation & -1 to -4 & $\begin{array}{c}\text { Amount of neutrophils, lymphocytes and } \\
\text { other inflammatory cells }\end{array}$ \\
\hline
\end{tabular}

Histopathological analysis was done by an experienced pathologist from Department of Pathology, UFRN, without knowledge of the study groups.

Statistical analysis was performed with SPSS 17.0 software, using ANOVA and Student's t-test, considering significant differences when $p<0.05$. 


\section{RESULTS}

Table 1 - Descriptive statistical results of ischemia/reperfusion variables, duodenal anastomosis bursting pressure and their inferential statistical tests.

\begin{tabular}{|c|c|c|c|}
\hline \multirow[b]{2}{*}{ Variables } & \multicolumn{2}{|c|}{ Groups } & \multirow[b]{2}{*}{ P-value } \\
\hline & $\begin{array}{l}\text { Hepatic I/R + } \\
\text { anastomosis }^{2}\end{array}$ & Anastomosis $^{2}$ & \\
\hline Body weight before (g) & $405.5 \pm 32.9^{¥}$ & $384.2 \pm 12.5 \dagger$ & $0.185^{1}$ \\
\hline Body weight after (g) & $373.2 \pm 34.4^{¥}$ & $376.0 \pm 9.8 \dagger$ & $0.850^{1}$ \\
\hline Bursting pressure $(\mathrm{mmHg})$ & $64.5 \pm 5.5$ & $89.7 \pm 3.4$ & $<0.001^{1}$ \\
\hline \multicolumn{4}{|c|}{$\begin{array}{l}\text { Average } \pm \text { Standard Deviation } \\
1-p \text {-value of Student } t \text {-test for independent samples. } \\
2-\text { Values }- \text { of the column - followed by similar symbols had statistically significant differences between } \\
\text { groups, from the Student's t-test for paired samples. }\end{array}$} \\
\hline \multicolumn{4}{|c|}{$\begin{array}{l}\text { In this study, two parameters to evaluate the healing process in the duodena } \\
\text { anastomosis were used; maximum bursting pressure of the anastomosis ano } \\
\text { histopathological analysis. After analyzing the results shown in Table } 1 \text {, there was a } \\
\text { significant difference between the maximum bursting pressure of the anastomosis } \\
\text { comparing hepatic } \mathrm{I} / \mathrm{R}+\text { anastomosis group and anastomosis group }(\mathrm{p}<0.001) \\
\text { Concerning to rats weight listed in the table } 1 \text {, there was no statistical significance in the } \\
\text { experiment. There were no deaths during the experiment. }\end{array}$} \\
\hline \multirow{2}{*}{ Variables } & \multicolumn{2}{|c|}{ Groups } & \multirow{2}{*}{ P-value ${ }^{1}$} \\
\hline & c IR + anastomosis & Control & \\
\hline Collagen & $1.83 \pm 0.41$ & $3.00 \pm 0.63$ & 0.007 \\
\hline Fibrosis & $1.17 \pm 0.41$ & $2.17 \pm 0.75$ & 0.023 \\
\hline Fibroblasts & $2.00 \pm 0.0$ & $2.00 \pm 0.0$ & 1.000 \\
\hline $\begin{array}{l}\text { Foreign body } \\
\text { reaction }\end{array}$ & $-2.83 \pm 0.41$ & $-1.33 \pm 0.52$ & 0.004 \\
\hline Inflammation & $-0.77 \pm 1.03$ & $-0.67 \pm 0.52$ & 0.727 \\
\hline
\end{tabular}

Mean \pm Standard Deviation

1 - non-parametric Mann Whitney`s p-value. 


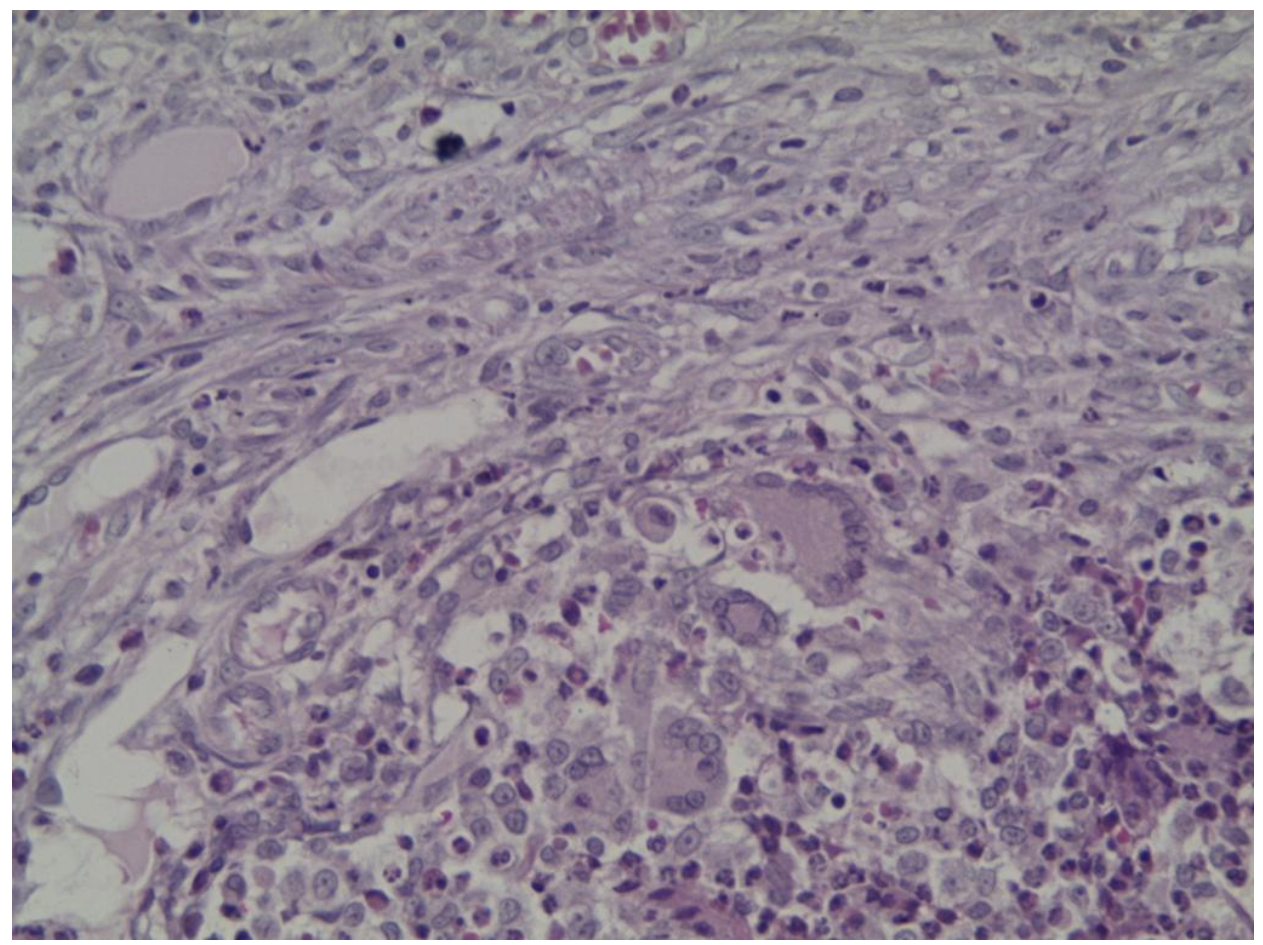

Figure 1 - Photomicrograph of the duodenum healing process of a Hepatic I/R + anastomosis group rat. Intense inflammation, small presence of collagen fibers. Masson trichrome staining. 200x

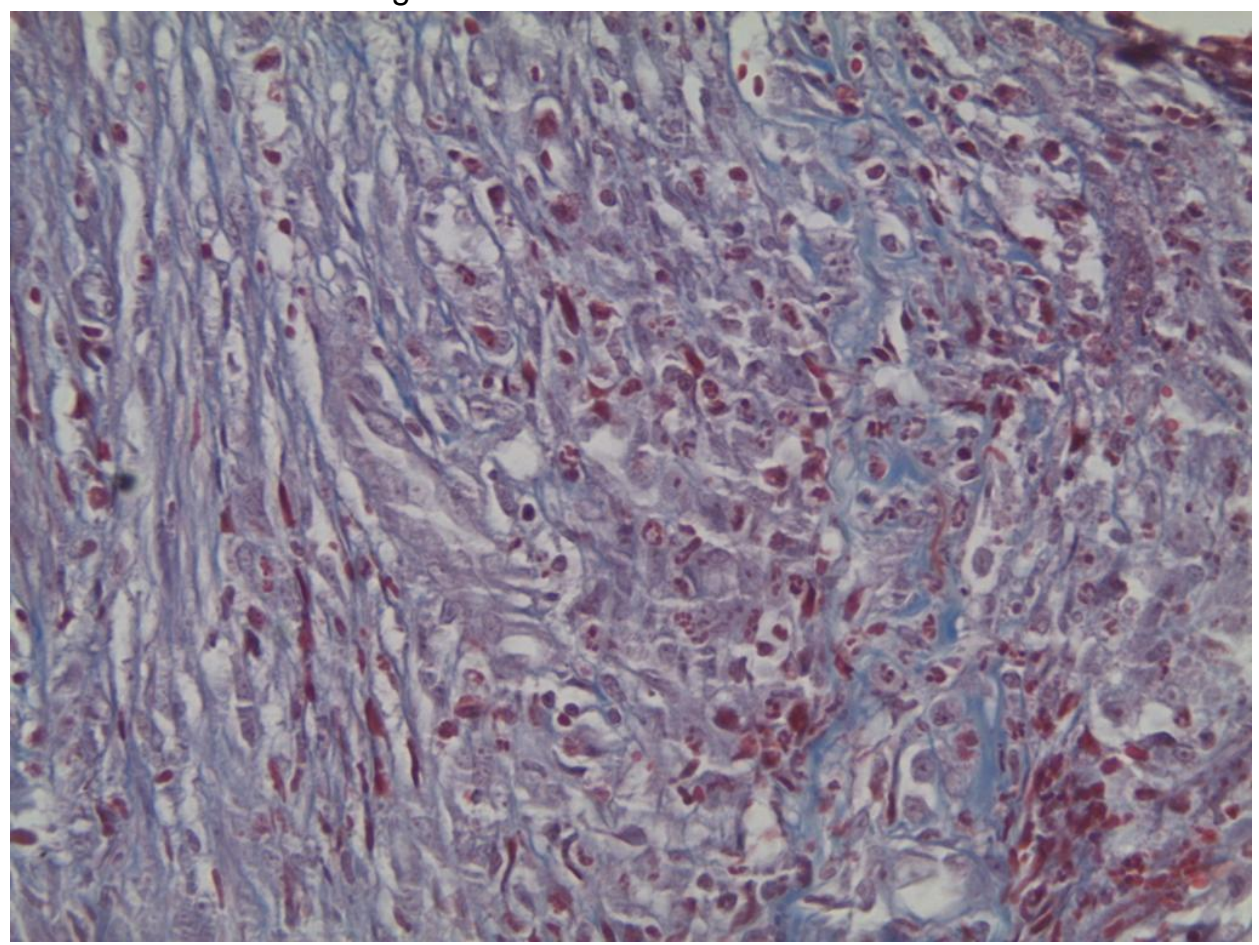

Figure 2 - Photomicrograph of duodenal healing process in anastomosis group rat. Intense presence of collagen fibers (blue), small inflammatory reaction. Trichrome Masson staining. 200x

Table 2 presents the results for the histopathology. The density of collagen and fibrosis had significantly higher values in the anastomosis group than in the hepatic $\mathrm{l} / \mathrm{R}+$ anastomosis group rats. The inflammatory response was significantly higher in the 
anastomosis areas in of the hepatic $\mathrm{l} / \mathrm{R}+$ anastomosis group rats than in the anastomosis group rats $(p=0.004)$. Figures 1 and 2 illustrate these findings.

\section{DISCUSSION}

Hepatic ischemia/reperfusion injury is common in surgical practice. It compromises the function of the liver and is associated with increased morbidity and mortality and postoperative complications, as the liver is an organ that demands high amounts of energy, and is extremely dependent on the oxygen supply. ${ }^{17}$ Ischemia/reperfusion injury is a phenomenon that involves two interrelated phases: the hypoxia that generates local tissue damage and the restoration of oxygen delivery which paradoxically causes systemic damage. $^{9}$

Through the Pringle maneuver, ischemia is caused by some surgical procedures such as transplantation, trauma, shock and elective liver surgery where the blood supply of the liver must be interrupted in order to carry it out. Although these operations are common, the mechanism of ischemia/reperfusion is still intriguing, involving numerous inflammation mediators and interactions still not well known. Furthermore, wound healing may be impaired by the release of such substances. ${ }^{14}$ However, the literature is scarce on this theme, and therefore this experimental study was designed to expand the understanding of this issue.

The results obtained in this study demonstrated that the liver ischemia/reperfusion injury interferes with the maximum bursting pressure of duodenal anastomosis of experimental rats. As already reported by Murat et al, ischemia followed by reperfusion promotes a systemic reaction, making the Pringle maneuver therefore possible and one of the procedures that results in hepatic $\mathrm{I} / \mathrm{R}$, exerting influence on duodenal anastomosis. As a result, inadequate healing interferes with the decrease in pressure sustained by the tissue in the area of the anastomosis; ischemia/reperfusion injury promotes activation of neutrophils, the complement system, pro-inflammatory and vasoactive mediators. ${ }^{14}$

In this regard, the anastomosis performed in the gastrointestinal tract generates an inflammatory process, which is part of the wound's healing process. As a result, proinflammatory and chemotactic properties as phenomena that occur during the healing of anastomoses, neutrophils activated by ischemia-reperfusion in an organ - in the case of this study, the liver - can accumulate easily in the anastomosis area, increasing the inflammatory reaction and healing time. ${ }^{14}$

Dogan et al. in 2014 analyzed the burst pressure of anastomoses in the left colon of rats undergoing intermittent Pringle maneuver. It was found that the bursting pressure 
of the anastomoses was lower in the group that underwent ischemic maneuver compared to the control group. They concluded that the Pringle maneuver may compromise the viability of colonic anastomoses. ${ }^{18}$

Ischemia/reperfusion, healing and liver physiology has been our research field ${ }^{19-21}$. There has been extensive research in the field of hepatic ischemia/reperfusion injury mechanisms/actions, particularly in animal models. Thus, this research is effective in encouraging further research for better understanding of this complex phenomenon. Since in the present experiment we used rats as models, further studies are required to make the application of this knowledge into clinical practice. Thus, the execution of this and future research will enable the development of new methods and procedures to prevent or reduce the damage by ischemia/reperfusion to a minimum in surgical practice.

In conclusion, our data showed that the hepatic ischemia-reperfusion negatively impacted the healing of duodenal anastomosis.

\section{REFERENCES}

1. Jorge Filho I. Cirurgia geral: pré e pós-operatório. São Paulo: Atheneu, 1995.

2. Medeiros AC. Conceituação da cicatrização das feridas cirúrgicas. Revista Saúde. 1992; 7:9-20.

3. Bezuti MT, Féres $O$, Campos $A$, et al. Cicatrização de anastomoses colônicas na vigência de obstrução intestinal. Acta Cir Bras. 2002;17:104-15.

4. Huget $\mathrm{C}$, Addario-Chieco P, Gavelli A, et al. Technique of hepatic vascular exclusion for extensive liver resection. Am J Surg.1992; 163:602-72.

5. Delva E, Camus $Y$, Nordinger B, et al. Vascular occlusions for liver resections. Operative management and tolerance to hepatic ischemia: 142 cases. Ann Surg.1989; 32:211-15.

6. Powner DJ. Factors during donor care that may affect liver transplantation outcome. Prog Transplant.2004; 14:241-49.

7. de Groot RUH. Ischemia-reperfusion injury: processes in pathogenetic networks. A rewiew. Transplant Proc. 2007; 39:481-95.

8. Tapuria N, Junnarkar S, Abu-Amara M, et al. Nitric oxide is an essential mediator of the protective effects of remote ischaemic preconditioning in a mouse model of liver ischaemia/reperfusion Injury. CI Sci. 2011;121: 257-66.

9. Jaeschke $\mathrm{H}$. Molecular mechanisms of hepatic ischemia-reperfusion injury and preconditioning. Gastrointest Liver Physiol. 2003; 284:15-26.

10. Malhi H, Gores GJ, Lemasters JJ. Apoptosis and necrosis in the liver: a tale of two deaths? Hepatology. 2006; 43:S31.

11. Serracino-Inglott $F$, Habib NA, Mathie RT. Hepatic ischemia reperfusion injury. Am J Surg. 2001; 181: 160-68.

12. Romanque UP, Uribe MM, Videla LA. Molecular mechanisms in liver ischemicreperfusion injury and ischemic preconditioning. Rev Méd Chile. 2005; 133:469-77. 
13. Henderson JM. Liver transplantation and rejection. An overwiew. Hepatogastroenterology.1999; 46:1482-90

14. Murat K, Kaya Y, Nurten R, Iskender S. Effect of local and remote ischemiareperfusion injury on healing of colonic anastomoses. Surgery. 2000;128:99-104.

15. Azevedo MA, Féres O, Rocha JJ, Aprilli F, Campos AD, Garcia RS. Efeito da icterícia obstrutiva na cicatrização de anastomoses colônicas em ratos. Acta Cir Bras. 2002; 17:55-58.

16. Ortiz DF; Lauand F; Campos AD; Rocha JJR; Feres O. Efeito da Drenagem Abdominal na Cicatrização de Anastomoses Colônicas. Estudo Experimental em Ratos. Rev Bras Coloproct. 2007;27: 63-68.

17. Papadopoulos D, Siempis T, Theodorakou E, Tsoulfas G. Hepatic Ischemia and Reperfusion Injury and Trauma: Current Concepts. Arch Trauma Res. 2013; 2:63-70.

18. Dogan M, Sen M, Koc M, Silig Y, Akyol G, Karadayi K, Turan, M. Effects of the Pringle manoeuvre on the healing of left colonic anastomoses in rats. Acta Chir Belg. 2014; 114:63-5.

19. Medeiros AC, Azevedo ACB, Oseas JMF, Gomes MDF, Oliveira FG, Rocha, KBF, Azevedo IM, Rego AC, Carvalho MDF. The ileum positively regulates hepatic regeneration in rats. Acta Cir Bras. 2014;29:93-8.

20. Felipe JC, Nascimento LAT, Souza GSS, Toledo LN, Medeiros VB, Azevedo IM, Medeiros A C. Coconut water as a resuscitation fluid and their effect on colon anastomosis healing in rats with hemorrhagic shock. J Surg CI Res. 2014; 5:80-91.

21. Medeiros AC, Brígido ARD, Silva SM, Brito VR, Rocha KBF, Oliveira CN. The ileum as a determinant organ of the functional liver cell mass in rats. Acta Cir Bras. 2013; 28:210-15. 